\title{
コータの高速化について
}

\author{
三蕣重工業株式会社 技術本部広島研究所 $\bigcirc$ 杉 原 正 浩 \\ 三菱重工業株式会社 紙印刷機械事業部 三 浦 洋 司
}

\section{Technologies for High-Speed Coating}

\author{
OMasahiro Sugihara \\ Mitsubishi Heavy Industries, LTD. Hiroshima R \& D Center \\ Hiroshi Miura \\ Mitsubishi Heavy Industries. LTD. Paper \& Printing Machinery Division
}

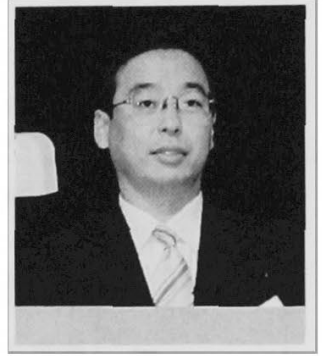

杉原正浩

Design speed of on- and off-machine coater has been increasing successively, and its operating speed will be beyond $2,000 \mathrm{~m} / \mathrm{min}$ in near future. Under such high-speed coating process, several technologies are required to maintain or improve the productivity and quality of coated paper.

In order to realize stable and efficient high-speed coating, stabilization of paper web behavior and suitable control of coating color flow are required. Improving the precision and response of control systems, reducing the several preparation times, and improving the drying efficiency are also required for high-speed coating. To serve these technical requirements, we have been carrying out several developments and improvements successively. In this paper, state of the art technologies for high-speed coating, such as "mist reduction system" for film coater, and "steam substitution system" for curtain flow coater, are reviewed briefly.

分類 : $\mathrm{N}_{3}$ 塗工機, $\mathrm{N}_{4}$ 塗工機付属設備

\section{1.はじめに}

紙コー夕、特にオフマシンコータの操業速度は近年 目覚しく高速化しており, 近い将来 $2,000 \mathrm{~m} / \mathrm{min} に$ 達するものと子測される”。このような高速叙工条件 下に扔いて塗工品質と操業性を維持/向上させるため には, 䤰工液, 洷工設備, 及び各種用具の高速対応技 術開発と高性能化が必須となっており, 各メーカでは 様々な研究開発がなされている。当社では, 高速化二 一スに対応するため, パイロットコー夕の最高塗工速 度を $2,800 \mathrm{~m} / \mathrm{min}$ とする改造工事"を行うと共に, 既 納機のフィールド調查を行い, 高速下で生じる様々な 現象の洗い出しと, 高速安定塗工を実現するための技
術開発を行っている。本報では, 上記の調査, 研究で 得られた高速塗工時における課題及び現象の発生メカ ニズムと,これに対応するフィルムコータのミスト低 隇法, カーテンフローコータの蒸気置換シールシステ ムなどの新技術について紹介する。

\section{2. 高速塗工時の課題と対応技術}

表 1は，ロッドメタリンダ, ゲートロール等のフィ ルムコータ, 及びオフマシンコータ各パートにおいて 高速渗工を行う際に発生する課題と，これに対する対 策を示したものである。また図 1 は, 表 1 に示した課 題を代表的な嗏工装置レイアウトに対応させて示した ものである。 


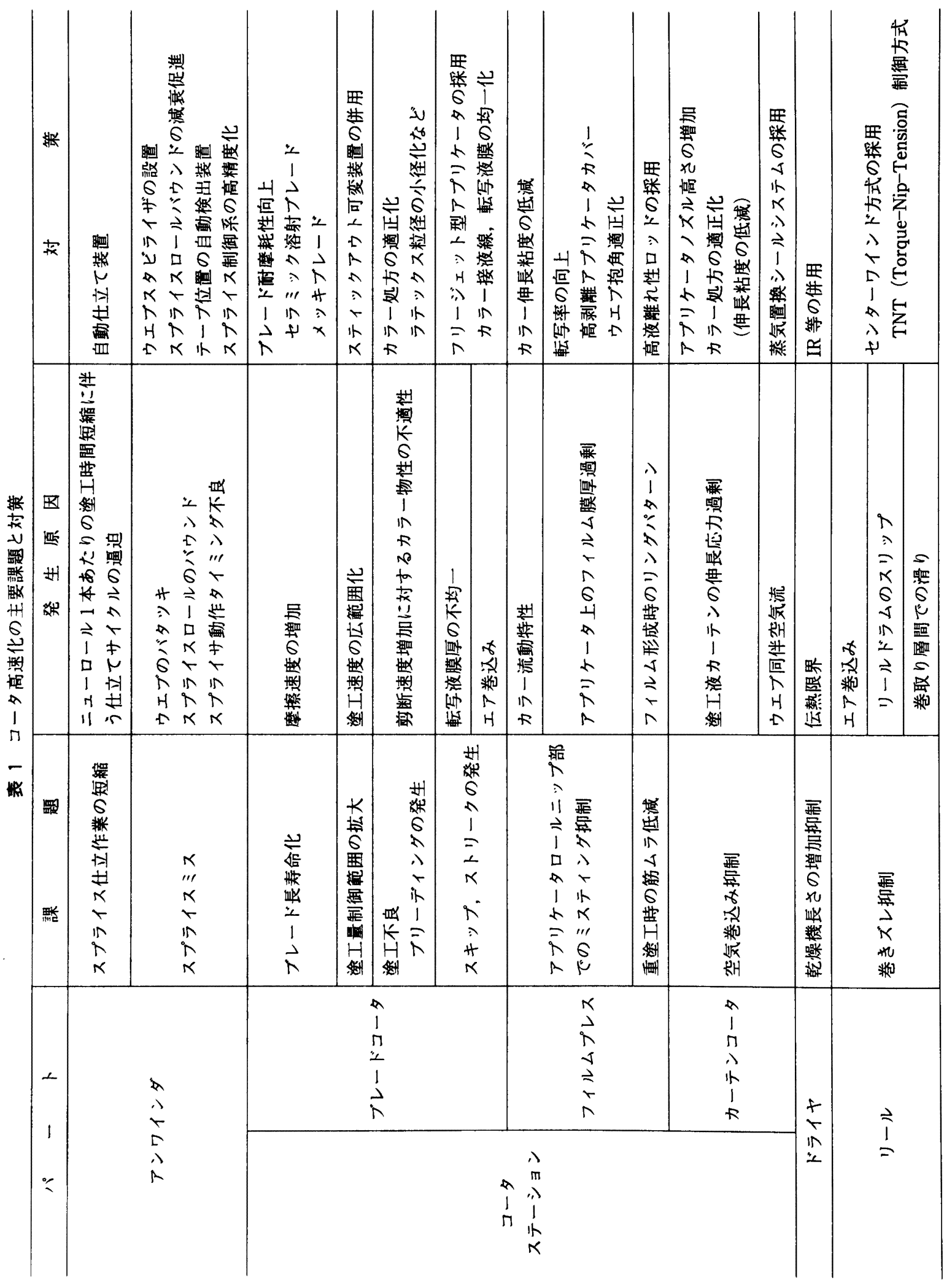




$$
\text { ブレードコータ }
$$
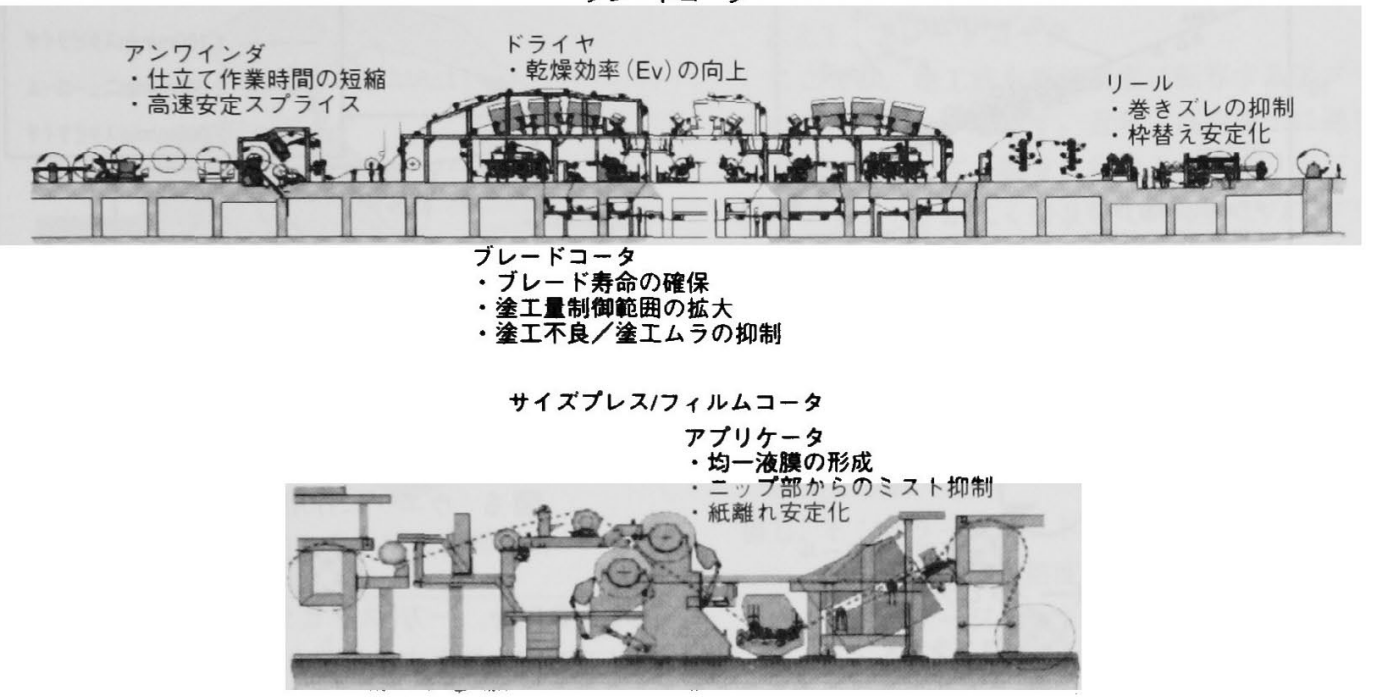

図 1 オフマシンコータ及びフィルムコータの概要と課題

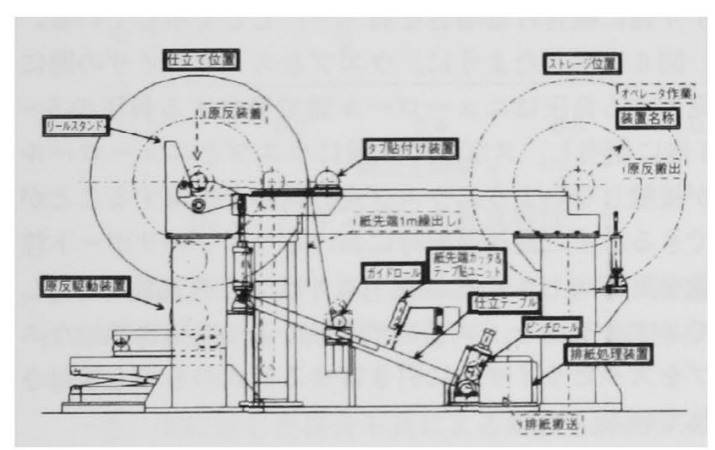

図 2 自動仕立装置の例

表1に示したように，高速染工時に必要となる技術 は主に空気及び染工液の高速流れに関連したものであ る。さらに,このような空気及び塗工液の流動に関す るものに加え，下記のような技術も必要となる。

(1)乾燥効率の向上

(2)計装・制御系性能の向上

(3)付帯作業の所要時間短縮

以下, 高速塗工時のウエブハンドリンク, 準工液流 動制御，及び空気巻込み抑制に関する現象とその発生 メカニスムについて示し，高速化を実現するための新 技術，及び付帯作業時間を短縮するための技術を，コ 一夕を構成するパート別に紹介する。

\section{1 アンワインダ}

澹工速度が高速になると原紙巻取り 1 本を塗工処理 する時問が短くなるため, スブライステープの仕立て 作業時間を短維する必要が生じる。これを短縮する方

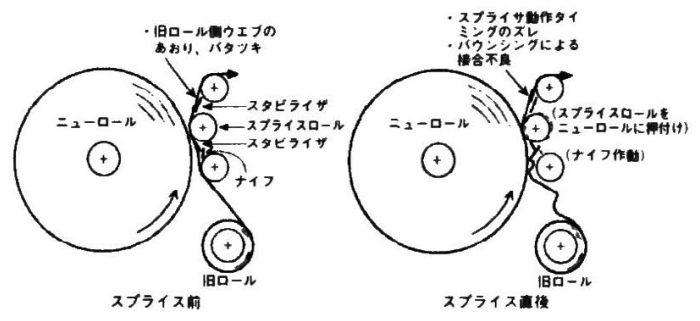

図 3 高速スプライス時にお忛る課題

法として，スプライステープの仕立て作業を自動化す ることが考えられる。図 2 は、スプライステープ及び タブテープの仕立てを自動で行う装置の一例を示した ものである。この装置の場合, 仕立て所要時間を 10 分以下にまで短縮することができる。

また高速下で安定した紙継き（スプライス）を行う ためには，図3に示すようなウエブ走行に関連した現 象を抑制・解消する必要がある。

ニューロールをウエプに接近させた状態で略同速ま で増速させる「スプライス前」の状態では, 走行中の ウエブに「あおり」,「バタッキ」といった現象が生 じることがあり，ニューロール上のテープとウエブの 表面が所定のスプライスを行う前に接触し, 断紙に繋 がる恐れがある。この現象の発生原因として,

1）ウエフの固有振動（ニューロール回転周期との 共振)

2) ウエフフフラッタ

3） スプライスロールとニューロールとの最小隙間 部出側でウエブに作用する負圧 


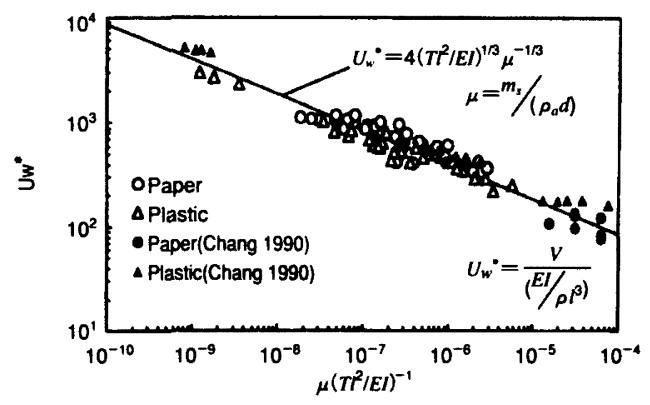

図 4 エッジフラッタ発生限界

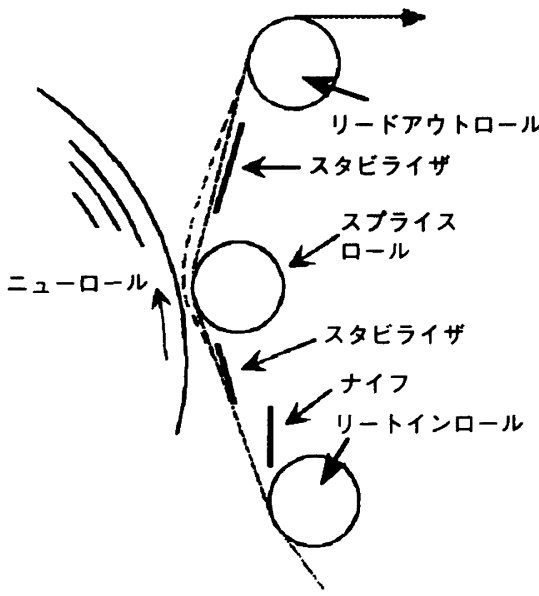

図 5 スタビライザ概要

などが考えられる。図4に示した著者らによるエッジ フラッタ発生限界把握害験”によれば，バタッキ現象 に影鳘を与える因子として, ウエフ速度 $V$, 張力 $T$, フリースパン長 $l$, 纸の曲げ哃性 $E I$, 坪量 $m$, 杂気 密度 $\rho_{\mathrm{a}}$, 秪幅 $d$, 及びニューロールとスブライスロー ル間の最小すきまが挙げられ2:314!，フラッタが発生す 万限界ウエフ速度が $l^{-1-1 / 3}, T^{1-1 / 2}$ に比例する傾向 が確認されている。この結果から，高速スブライス時 のウエプのバタッキを抑えるため，スプライスロール とリードイン及びリードアウトロールとの距離を短く， またウエフの張力を高めに設定する必要があることが わかる。

上記のほか，図５に示すような平板状のスタビライ ザを装着してウエプのバタッキを抑える方法がある゙”。 このスタビライザは，デイフューザ効果によってウエ ブスタビライザ側に引き付け，紙継ぎ前にウエフが ニューロールと接触することを防いでいる。图 6 は， スブライスロール〜リードアウトロール間でウエフに 作用する圧力分布を示したものである。図中の凡例に 示した「ニューロール」はウエフとニューロール間に発

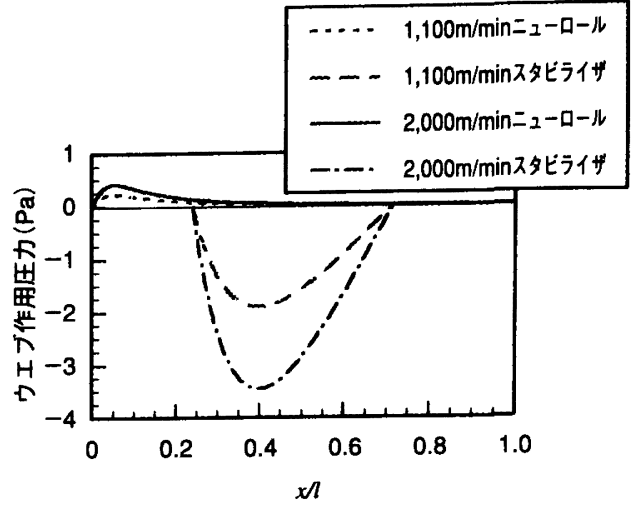

図 6 ウエブに作用する空気圧力 (スプライス部出侧領域)

生する負圧を，一方「スタビライザ」はウエブとスタビ ライザの間に発生する負圧を，それぞれ示している。 また縦軸に示したウエブに作用する圧力は, ウエブを ニューロール側に吸付ける場合を正 $(+)$, スタビラ イザ㑡に吸付ける場合を負（一）として示している。

図6に示したように, ウエフとスタビライザの間に 発生する負压はニューロール側で発生する負圧の5〜 8 倍に相当し，スプライス前にウエブとニューロール が接触しないようにウエブ走行軌跡を拘束することが できる。また高速運転時におけるウエフのサポート性 能を更に向上させるため，スタビライザ上面と平行し てエアを噴出し，コアンタ効果によって積極的にウエ フをスタビライザ側に引き寄せる形式のものも検討さ れている。

次に，高速下での新旧ウエブ接合ブロセスでは，二 ューロールの回転周期が短いため，以下に示すような 問題が生じる恐れがある。

（1）スプライスロールがニューロールと接触する夕 イミンクの僅かなズレ，及びナイフによる旧ウエ フ切断タイミングの僅かなズレによる紙継ぎ失敗。

(2) スプライスロールニッブがニューロールと衔突 した際に生じる振動，スプライスロールのバウン ド (バウンシンク）の堿衰不足による新旧ウエブ の接合不良

上記のうち，(1)の問題はスブライサを正確な（再現 性の良い) タイミンクで動作させることにより解消さ れる。これを実現するためには，スプライサの動作基 準となっているスブライステーブ位置を正確に検知す る必要がある。図7は，現在手動で入力されているス ブライステーブ位貫を正確に自動入力するための自動 検出装置の例を示したものである。この装固では, 光 学センサによりスプライステープ位置を検出し，スフ 


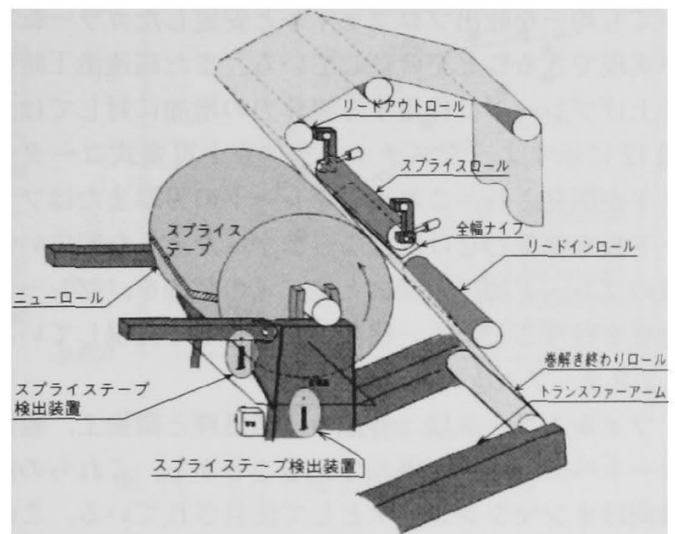

図 7 スプライステープの自動検出

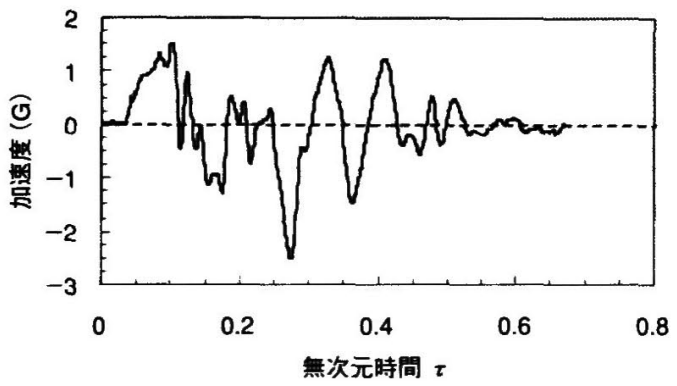

図 8 バウンジング減衰特性

ライサ制御系に入力する仕組みとなっており，高速下 においても正確且つ再現性の良いスプライサ動作が得 られる。

一方，(2)に示した接合不良による断紙を抑制するた めには，バウンシングを少なくともニューロールが 1 回転するまでの間に減衰させる必要がある。図 8 は, 紙継き時においてスブライスロールに作用する加速度 の計測例を示したものである。図中の横軸に示した無 次元時間は，実時間をニューロールの回転周期で無次 元化したものであり，紙継ぎを行う時刻が $\tau=1$ とな る。図 8 に示した例では, $\tau \div 0.55$ でほほバウンシン グが減衰しているため，スブライスに対するバウンシ ングの悪影響はない。バウンシング減衰時間が一定の 場合，速度が増加するとニューロールの回転周期が短 くなるため, 無次元バウンシング減衰時間は 1 に近づ く。よって，高速でも安定したスプライスを得るため には，バウンシングを出来るだけ早期に減衰させるこ とが必要である。バウンシンクを短時間で隇衰させる ためには, ショックアプソーバの滅衰特性強化とスプ ライサ重量の軽量化が有効である。

\section{2 コータステーション}

次に，染工装置（コーダステーション）の高速化に
おける課題と対応技術について示す。

\subsection{1 ブレードコータ}

ここでは, 塗工液を原紙表面に転写するアプリケー タの高速化について示す。近年, 高速塗工に適したア プリケータとして, 図9に示すようなフリージェット 型アプリケータが広く普及している。このアプリケー 夕を用いて安定したカラー転写を行うためには, アフ リケータノズルから噴出したジェットに作用するスト レス（伸長応力）をできるだけ低くすることが重要で ある”。ここで, カラージェットに作用する伸長応力 は,

$\tau \propto \eta d V / d x$

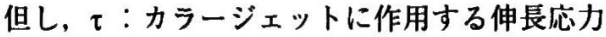

$$
\begin{aligned}
& \eta: \text { : ラー伸長粘度 } \\
& V: \text { カ カージェット平均流速 } \\
& x \text { : カラージェット流れ方向座標 }
\end{aligned}
$$

で示されることから, 塗工速度の増加に伴って原紙走 行速度とカラージェットの速度差が大きくなり, 伸長 応力が高くなることがわかる。この伸長応力が過剩に なると, 塗工液ジェット流れ, 及びジェットと原紙が 接液する領域の状態が不安定になり, 空気巻込みなど の不安定転写現象に撃がる恐れが生じる。これを避け るためには，カラーの伸長粘度を適正に選定すること

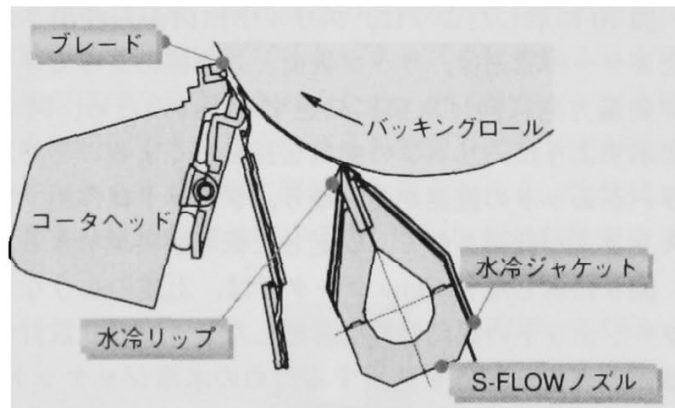

図 9 フリージェット型ブレードコータ (S-Flow コータ)
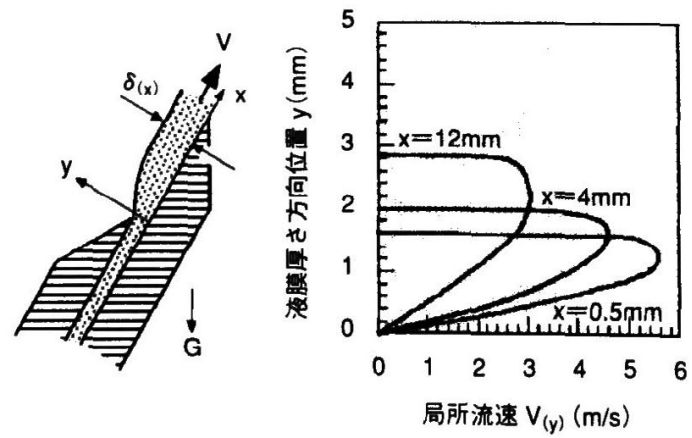

図 10 流れ場の概要と液膜厚さ方向速度分布 


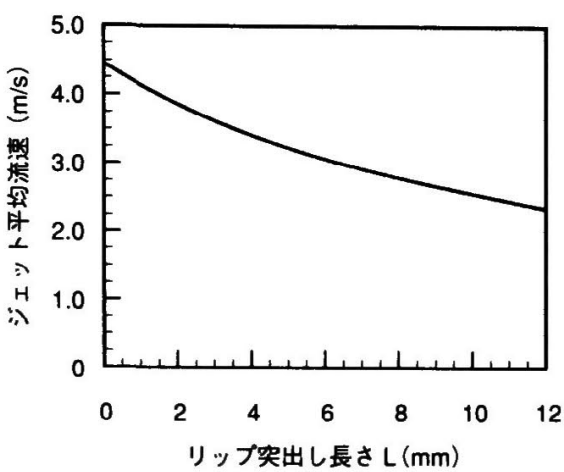

图 11 リップ突出し長さとジェット平均流速

と、ジェットの流速をできるだけ速くすることが必要 である。

カラージェット流速を速くする方法として，スリッ 卜隙間を狭くするほか，スリットリップの突出し長さ を短くすることも有効である。図 10 はリップ上にお ける染工液流速の厚さ方向分布のシミュレーション結 果, また図 11 はリップ突出し長さに対するカラージ エット平均流速のシミュレーション結果を，それぞれ 示したものである。計算条件は, カラー流量 $6.7 \times 10^{-3}$ $\mathrm{m}^{3} / \mathrm{sec} / \mathrm{m}(2,000 \mathrm{~m} / \mathrm{min}$ 転写膜厚 $200 \mu \mathrm{m}$ 相当 $)$, 力 ラー粘度 $0.45 \mathrm{~Pa} \mathrm{sec}$ である。

図10に示したように，スリット出口から吐出され たカラーの流速は、リップ表面との摩擦によってリッ プ先端方向に向け次第に減速する。このため, 図 11 に示すように, リップの突出し長を短くすることでカ ラージェットの流速が速くなり，ジェットに作用する ストレスが低隇されて，安定した転写が実現できる。

図 9 に示したS-Flow コータでは，上述のようなカ ラージェットの流動特性を考虑したリップ形状設計の ほか，カラー固着を防止するための水令ジャケット/ リップの装着, 高速塗工時におけるカラー流量增加に 対応したスリット/マニフォールド流路設計などを行 い, パイロットコータで塗工速度 $2,800 \mathrm{~m} / \mathrm{min}$ にお

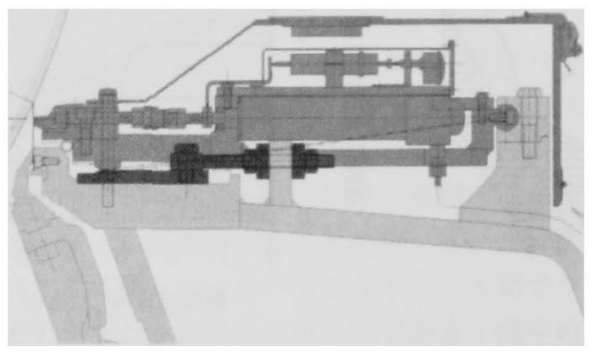

図 12 新型ブレード加圧機構
いても均一な吐出プロファイルと安定したカラー転写 が実現できることを確認している。また高速塗工時に 仕上げブレードに作用する流体力の增加に対しては, 図 12 に示すようなスティックアウト可変式コータへ ッドが開発され、これまでブレードの刃厚またはフレ ード長を変更しなければならなかったような幅広い領 域のブレード加圧力制御と塗工量の制御を, ブレード 変更を行うことなく一種類のブレードで実現している。 2.2.2 フィルムコータ

フィルムコータは, 外添サイズ処理と微塗工, 軽量 コートへの対応性に優れていることから，これらの紙 種向けオンマシンコータとして注目されている。この フィルムコータで高速高品質塗工を実現するためには, ミスト発生量の低減が必須であることから，近年アプ リケータロールニッブ出側で発生するミスティング現 象に関する研究が盛んに行われている6。

ミスティング現象の発生メカニズムは，一般に，ア プリケータロールニップ出側で塗工液膜が分裂する際 に塗工液の「糸引き (filament formation)」が発生し, これが崩壤することによって生じる，と説明されてい るら。そこで著者らは，パイロットコータを用い，実 際の紙用塗工液でミスティングが発生する様子の可視 化を試みだ。図13は，アプリケータロールニップ出 側におけるミスト発生状況を可視化した結果を示した ものであり，実験条件は以下の通りである。

・アプリヶータロール周速： $600 \mathrm{~m} / \mathrm{min}$

・アプリケータロール上液膜厚：15 $\mu \mathrm{m}$

・供試染工液粘度特性：

B 型 $(60 \mathrm{rpm}) \cdots 1.25 \mathrm{~Pa} \mathrm{sec}$

べき乗則モデル… $\eta_{\mathrm{o}}=2.11 \mathrm{~Pa} \mathrm{sec}{ }^{\mathrm{n}}, \mathrm{n}=0.64$

・原紙有無：無し（ロール転写）

\section{(Nip Region)}

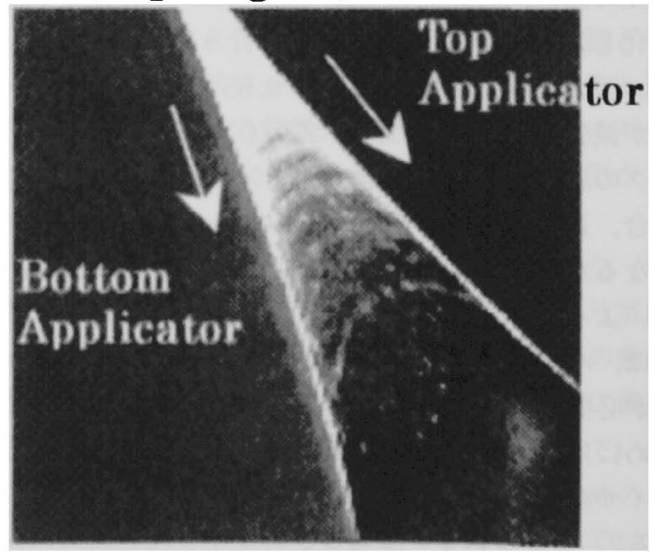

図 13 ニップ出側での釆引き 


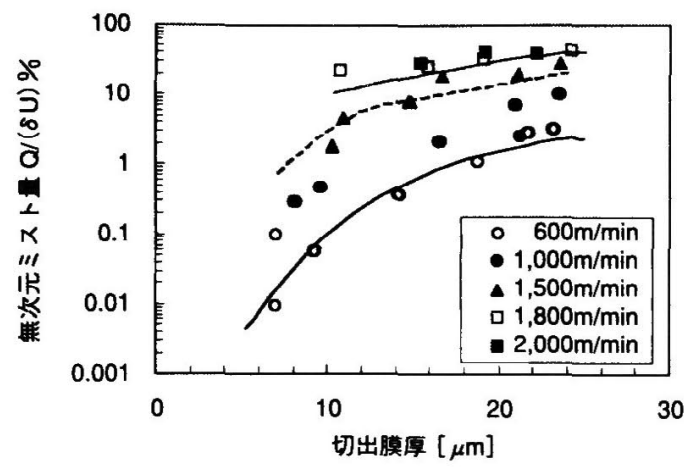

図 14 ミスト発生量計測結果例

図13に示したように, ミスティング現象は明らか に鋈工液膜分裂時の系引きが崩壊することによって発 生していることが確認された。

図 14 は紙無し（ロール転写）テストで計測したア プリケータロール上の塗工液膜厚に対するミスト発生 量を，アプリケータロール周速別に示したものである。 図中の縦軸に示したミスト量は,アプリケータロール 上に形成されている塗工液膜の流量（ $\delta=$ 塗工液膜厚 さ， $\mathrm{U}=$ ロール周速）で無次元化して示している。図 14 に示したように，ミスト発生量はロール上の塗工 液膜厚およびアプリケータロール周速の增加に伴って, 急激に增加する傾向を示している。

このような実験で得られたミスト発生特性に基づき， 図15に示すようなフィルムコータ（MJフィルムコ ータ）を開発した。このコータでは，原紙をアプリケ ータロールに抱かせることで原紙への塗工液浸透を促 進し，紙離れ位置における淘工液膜を不動化してミス ト発生量を低減している。また,アプリケータニッフ 出側の紙離れ位置には小型のエアターンバーが設圈さ れ, 秪離れの安定化と塗工面の非接触サポートを行っ ている。

図 16 は，上述の高速フィルムコータにより 1,500 $\mathrm{m} / \mathrm{min}$ でピクメント塗工を行った場合のミスト発生 量低減効果を示したものである。図 16 に示したよう

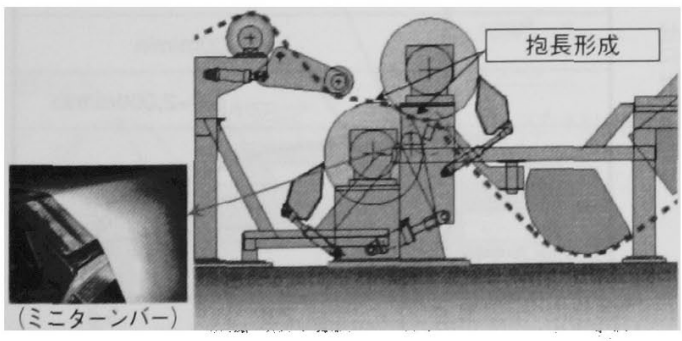

図 15 高速フィルムコータ（MJコータ）

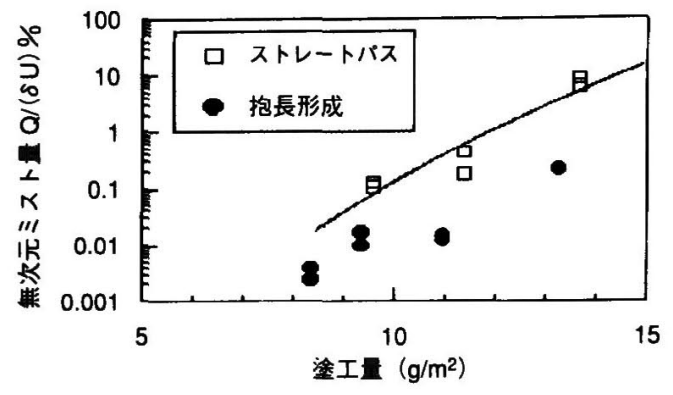

図 16 ミスト低減効果

に，この実験では抱長形成を行うことによって，フィ ルムコータで発生するミスト量が, 従来のストレート パス（抱長ゼロ）に比較して約 $1 / 10$ 程度にまで低減 された。

このほか, フィルムコータの塗工品質向上を目的と して, $10 \mathrm{~g} / \mathrm{m}^{2}$ 以上の塗工を行う場合においてもリン グパターンによる筋ムラが発生しないロッドの開発, 高剥離アプリケータロールの開発・検証なども，パイ ロットコータを用いて行っている。

\subsection{3 カーテンフローコータ}

カーテンフローコータは, ブレード, アプリケータ ロールといった原紙と直接接触する部材がないことか ら，断紙の低減，摩耗部品の削減など生産性の向上に 有効であり，更にアプリケータノスルに供給された治 工液がほほ全量塗工されるため，塗工量がポンプ流量 で直接制御でき，且つ給液系の設備，エネルギが従来 のコータよりも大幅に削減できる点からも，次世代コ 一タとして注目されている”。しかしながら従来のカ

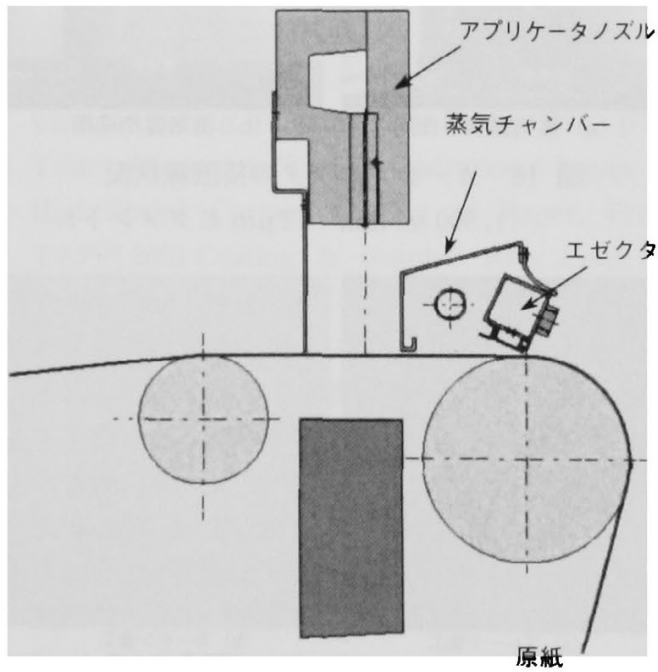

図 17 高速カーテンフローコータ 
ーテンフローコータでは，塗工液膜と原紙表面との間 に空気巻込みが生じ易いことから，高速での塗工には 不向きとされていた。

これに対し，当社ではエゼクタにより原紙に対向し てエアジェットを吹付けて同伴空気流を除去した後, 塗工液カーテンと原紙が接液する領域を水蒸気で置換 する「蒸気置換シールシステム」を装備した新型高速 カーテンフローコータを開発し, $800 \mathrm{~mm}$ 幅パイロッ トコータにて最高塗工速度 $1,700 \mathrm{~m} / \mathrm{min}$ までのピク メント叙工に成功しだ'。図17は, 蒸気置換シールシ ステムを装備した高速カーテンフローコータの構成概 要を示したものである。また図 18 は, 蒸気置換シー ルシステムの有無による塗工液カーテン接液状況を示 したものである。なお図 18(a)は蒸気置換シールシス テム不使用の場合，(b)は作動させた場合のカーテンの 状況をそれぞれ示しており，塗工速度は $1,500 \mathrm{~m} / \mathrm{min}$, 供試液は濐度 $54 \mathrm{wt} \%$ のピクメントカラーである。

蒸気直換シールシステムを使用していない(a)の場合 には，カーテンの接液線が乱れ，塗工液膜下に空気が 浸入している。一方，(b)に示した蒸気置換シールシス テムを使用した場合の接液線は紙幅方向に均一かつ安 定したものとなっており, 高速で気泡浸入の無いカー

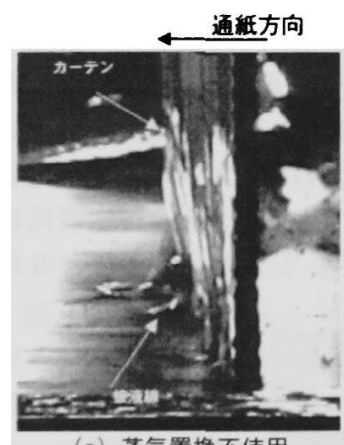

(a) 蒸気置換不使用

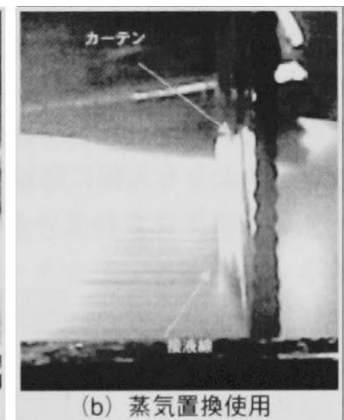

(b) 蒸気置換使用
図 18 カーテンコータの接液線状況 $(1,500 \mathrm{~m} / \mathrm{min} 12 \mu \mathrm{m}$ ピグメント $)$

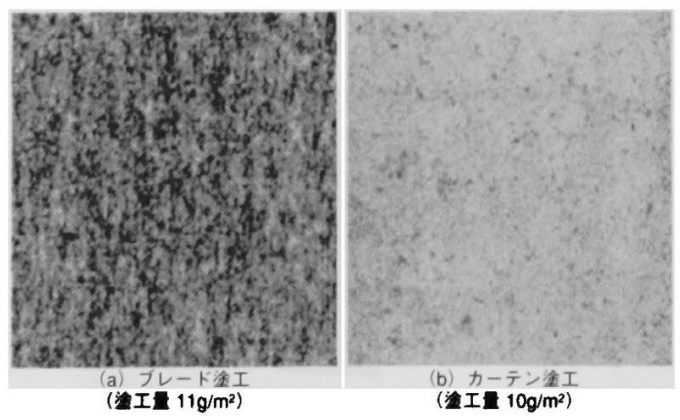

図 19 サンフル表面被覆状況
テンフロー塗工が可能となった。

図19は，ブレード及びカーテンフローで塗工した サンプル紙をバーンアウト（炭化）処理したものであ る。図中, 白色部が叙工層で被覆された領域を示して いる。なお供試酒工液は, 濃度 $60 \mathrm{wt} \%$ （B 型 $60 \mathrm{rpm}$ 粘度 $600 \mathrm{mPa} \mathrm{s}$ ) であり, 双方同一の原紙を使用して いる。図19に示したように, カーテンフローコータ で塗工したサンプルの表面被覆性は，ブレードコータ で塗工したサンプルよりも良好なものとなっている。 このような被覆性の差が現れた原因は，原紙内への塗 工液浸透量が異なるためである。即ち, ブレードコー タでは仕上げブレード下で発生する圧力でカラーが原 紙内に浸透し，原紙表面上に残留するカラー層が薄く なっているものと考えられる。これに対し，カーテン フローコータでは原紙内への塗工液の浸透量が少ない ため,カラー層が概ね原紙表面上に残留し，原紙被覆 性が向上する。

以上に示したように, カーテンフローコータに蒸気 置換シールシステムを装備することによって，高速で 被覆性の良い塗工紙の製造が可能となっている。

\section{3 リ $-ル$}

高速で㓌工紙を巻き取る場合には，巻き硬さが軟ら かくなる傾向を示すことがある。これは, 塗工紙の通 気抵抗が高く，巻取り秖の層間に侵入した空気が抜け ないため生じる現象である。このような現象が生じる と, 巻取り紙層間の摩擦が低下し，蛇行，巻きズレな どの不具合に慗がる恐れがある。

图 20 は, A 3 染工紙 (ガーレー透気度 $7,118 \mathrm{sec})$ を巻き取る場合における紙層間圧力を，卷取り速度毎 にシミュレーションした結果を示したものである”。 図中の絴軸に示した層間圧力比は, 速度 $1,400 \mathrm{~m} / \mathrm{min}$ 時のスプール表面における層間圧力を 1 としたもので ある。図 20 に示したように，層間圧力は巻取りの外

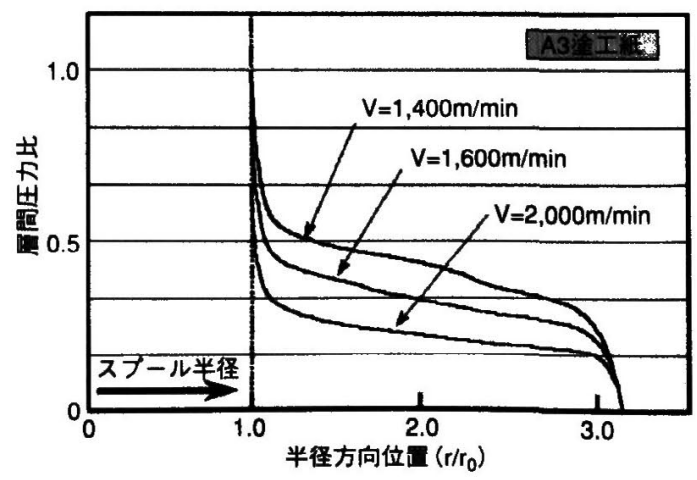

図 20 速度変化に対する層間圧力分布の変化 


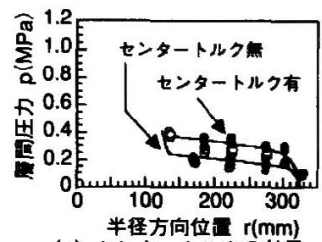

(a) センタートルクの她果

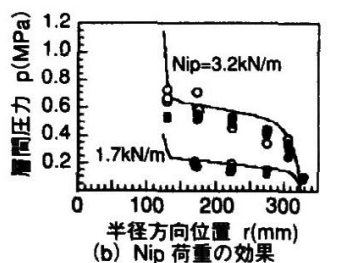

(b) Nip 荷重の奻果

図 21 巻き硬さに対するセンタートルクとニ ップ荷重の影敀

㑡ほど低くなる傾向を示す。これは，巻取り半径の增 加に伴って，空気が巻込み易くなることによるもので ある。また，巻取り速度の增加に伴って層間圧力は低 下し, $2,000 \mathrm{~m} / \mathrm{min}$ における層間圧力は $1,400 \mathrm{~m} / \mathrm{min}$ の場合の $50 \%$ 近くまで低下する可能性が考えられる。

高速下で詹間圧力を維持するためには，リールドラ ムニップ荷重の增加と, 巻取りのセンターワインド化 が必要不可欠である。図 21 は, ニッフ荷重の変化, 及びセンタートルクの有無に対する巻取り層間圧力の 変化を示したものである。図中の実線は前述のシミュ レーションによる予測結果, プロットは小型要素試験 機による実測結果を，それぞれ示している。なお，(a)

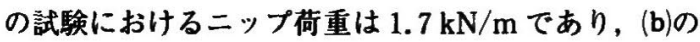
試験ではセンタートルクは作用させていない。

図 21 に示した試験では，巻取りをセンターワイン ド化することによって層間圧力を的 2 倍にまで上昇さ せることができた。また（b）に示したようにニッ プ荷重を $1.7 \mathrm{kN} / \mathrm{m}$ から $3.2 \mathrm{kN} / \mathrm{m}$ まで增加させた場 合には，層間圧力は約 3 倍に上昇している。なお（b) に示したニッブ荷重を增加させた場合においても，巻 取りにセンタートルクを作用させることにより，概ね （a）と同じ割合で層間圧力を上昇できることが確認さ れている。このように，七ンタートルクを併用するこ とで，低いニッフ荷重で同一の巻き硬さを得ることが 可能となる。

上述のように，巻取りにセンタートルクを作用させ ることにより，高速下においても適切なリールドラム

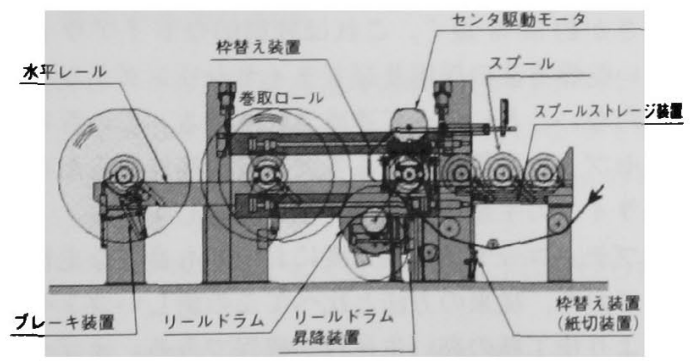

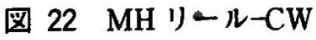

のニップ荷重で十分な巻き硬さを得ることが可能であ る。このような巻き硬さに対する検討に加え，下巻き のシワ防止などを可能としている高速向けリール （MHリール-CW）を，図22に示す。このリールで は，高ドラムニッブ荷重対応，七ンターワインドに加 え，スプールが水平レール上をりニアに動く構造とす ることでニッブ, トルクの変動要因を無くして, 高速 下でも安定した巻取りを実現している。

3.むすび

以上,コー夕の高速化に対する課題と対応技術につ いて，当社の最近の研究開発事例に基き概観した。近 年の䛔しい塗工紙の生産事情に対応していくためには, 生産技術に寄与する設備の技術向上が必要である。今 後，更に市場ニースに応える新製品/新技術の開発に 取組んでいく所存であり，業界各位のご意見，ご協力 をお願い申し上げる。

\section{参考文献}

1）杉原ら：三菱コー夕高速化への取組み，紙パ技協 誌 55 (4) 12 (2000)

2) Pramila. A : Sheet flutter-An analytical and experimental study. Tampere Univ. Rep. No. 30, Tampere Univ. of Tech. (Dept. Mech. Eng. Appl. Mech.) (1985).

3) Chang. Y.B.: An experimental and analytical study of web flutter, PH. D. Thesis, Oklahoma state Univ. (1990).

4）渡部：紙のフラッターに関する研究, 博士論文, 九州大学大学院工学研究科（航空工学部門） (2001).

5）三菱重工，実案 2503149.

6）例えば Fernando, R.H., Proc. 1999 TAPPI Advanced Coating Fundamentals Symp. ('99), p 99.

7) Triantafillopoulos, N., et.al., Operational Issues in High-Speed Curtain Coating of Paper, Proc TAPPI 2001 Coating \& Graphic Arts Conf. \& Trade Fair (May, '01), p 251.

8）杉原ら：高速カーテンフローコータに扔ける空気 巻込み抑制に関する研究, 化学工学会第 34 回秋 季大会く塗布技術と表面加工〉シンポジウム講演 要旨集 ('01.9) 揭載予定.

9) Tanimoto, K., IN-ROLL STRESS ANALYSIS OF WOUND ROLL WITH THE AIR ENTRAINMENT AND THE PERMEANCE, Proc. of the Sixth International Conference on Web Handling (June, '01). 


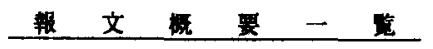 \\ コータの高速化について \\ 三菱重工業株式会社 技術本部広島研究所 杉原 正浩 三菱重工業株式会社 紙印刷機械事業部 三浦 洋司}

紙コータ, 特にオフマシンコータの操業速度は近年目覚しく高速化しており, 近い将来 $2,000 \mathrm{~m} / \mathrm{min}$ に達するものと予測される。このような高速塗工条件下において塗工品質と操業性を維持・向上させる ためには，塗工液，塗工設備，及び各種用具の高速対応技術開発と高性能化が必須となっており，各メ 一カでは様々な研究開発がなされている。当杜では, 高速化ニーズに対応するため, パイロットコータ の最高望工速度を $2,800 \mathrm{~m} / \mathrm{min}$ とする改造工事を行うと共に, 既納機のフィールド調查を行い, 高速 下で生じる様々な現象の洗い出しと，高速安定塗工を実現するための技術開発を行っている。本報では, 上記の調査, 研究で得られた高速塗工時における課題及び現象の発生メカニスムと, これに対応するフ イルムコータのミスト低減法，カーテンフローコータの蒸気盖換シールシステムなどの新技術について 紹介する。

(本文 39 ベージ)

\section{最新の塗工技術について \\ 一高速かつ高品質のコーティングテクノロジーー}

住友重機械工莱株式会社 結城 幸一

最新の望工技術は日々進歩しているが塗工装置に対する要求は高速化を実現する一方，高品質の紙を 生産することも求められている。これらは時として相矛盾するが, 染工装置の開発はこれらを同時に実 現することを目的にしている。

メッッォ社では染工装置として，世界最高速度のブレードコータに暗用されており，ジェットファウ ンテンタイブである Opti-Coat Jet, 従来のショートドウェルコータの改良型である Opti-Blade, 高染 工量向けの Opti-Coat Duo，新しいフィルム転写型コータの Opti-Sizer があり，これらの染工装置は現

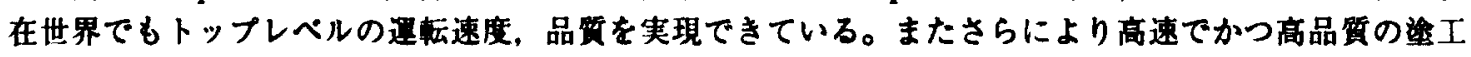
面を得ることができ，ウェフに対して非接触で㤠工が可能なスプレーコート方式の Opti-Spray を新た に開発した。

これら一連のコーティンク装置はメッツォ杜のオブティコンセフトの一部であるオブティコータを楼 成している。

(本文 48 ページ)

\section{各種コータヘッドと対象製品について}

株式会社アイ・エイチ・アイフォイトベーバテクノロジー 佐タ 忠

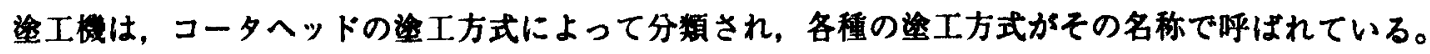
その対象となる製品については，製品が要求される用途や目的に応し，俭工方式の特徴を生かしたコー タヘッドを選択し生産されている。

印刷望工用紙用コータの世界的主流はフレードコータである。フレードコータは端的に言って印刷用 紙の最も重要な品質の一つである，優れた平滑性が得られる。さらに高速叙工に極めて適しており広い 